\title{
The Effect of Training Type on Oxidative DNA Damage and Antioxidant Capacity during Three-Dimensional Space Exercise
}

\author{
Keun Su Kim ${ }^{a}$ II Young Paik ${ }^{b}$ Jin Hee Woo ${ }^{d}$ Byung Yong Kang ${ }^{c}$ \\ ${ }^{a}$ Department of Physical Education, R.O.K. Air Force Academy, ${ }^{b}$ Department of Physical Education, Exercise \\ Physiology Laboratory, Yonsei University, and ${ }^{C}$ Department of Physical Education, Hanyang University, Seoul; \\ ${ }^{\mathrm{d}}$ Department of Physical Education, College of Sport Science, Dong-A University, Busan, Korea
}

\section{Key Words}

Three-dimensional space exercise • Free radicals •

Oxidative stress

\begin{abstract}
Objective: Orbotron training is a popular training method for fighter pilots because it replicates a high-acceleration environment with excessive G-force. The purpose of this study was to investigate the effects of 9 weeks of orbotron training on oxidative DNA damage and antioxidant capacity in humans during 3-dimensional space exercise. Subjects and Methods: The subjects comprised 15 senior cadets from the Korea Air Force Academy who had no record of medical disorders and who participated in a regular exercise program (3 times per week). They were randomly divided into three groups consisting of 5 subjects each: a weight training group (21.97 \pm 1.12 years), a running training group $(21.53 \pm 0.18$ years) and an orbotron training group (21.48 \pm 0.29 years). Three-dimensional exercise tests were performed before and after training, and blood samples were taken to measure the concentration of plasma lactate, malondialdehyde (MDA), erythrocyte superoxide dismutase (SOD) activity, and leukocyte DNA damage. Results: Plasma lactate concentrations decreased in all three groups when measured after training and after 30 min of recovery compared to before training $(p<0.05)$. The concentration of plasma MDA
\end{abstract}

\section{KARGER}

Fax +4161306 1234

E-Mail karger@karger.ch

www.karger.com
(C) 2010 S. Karger AG, Basel

$1011-7571 / 10 / 0192-0133 \$ 26.00 / 0$

Accessible online at:

www.karger.com/mpp also decreased after training in all blood samples compared to the values obtained before training although there was no significant difference in the weight training and orbotron training groups. In contrast, the activity of erythrocyte SOD increased for all three groups compared to before training $(p<0.05)$. In the comet assay results, the greatest lymphocyte DNA damage was demonstrated at the end of exercise compared to the other three samples under all conditions, and these aspects were commonly observed in all three parameters of lymphocyte DNA damage (tail DNA, tail length and tail moment) $(p<0.05)$. Conclusion: It can be concluded that the three types of exercise training reduced plasma lactate concentration, improved antioxidant enzyme activity, and further protected the body against oxidative stress (lipid peroxidation and DNA damage). Although we have identified an effect of exercise training on the levels of antioxidants and oxidants, our cohort was small, so further studies are needed to evaluate the different types of exercise training.

Copyright $\odot 2010$ S. Karger AG, Basel

\section{Introduction}

As air force pilots undertake missions in special 3dimensional environments different from those on the ground, they experience physiological changes and oxi- 
Table 1. Physical characteristics of the study subjects

\begin{tabular}{lllllll}
\hline Group & $\mathrm{n}$ & Age, years & Height, $\mathrm{cm}$ & Weight, kg & BMI & Body fat, \% \\
\hline WT & 5 & $22.0 \pm 1.1$ & $174.7 \pm 3.8$ & $74.2 \pm 8.7$ & $24.3 \pm 2.2$ & $17.1 \pm 4.1$ \\
RT & 5 & $21.5 \pm 0.2$ & $175.0 \pm 4.9$ & $73.7 \pm 4.9$ & $24.0 \pm 0.4$ & $17.6 \pm 1.3$ \\
OT & 5 & $21.5 \pm 0.3$ & $173.3 \pm 3.0$ & $71.9 \pm 12.8$ & $23.9 \pm 3.6$ & $18.8 \pm 7.1$ \\
\hline F value & & 0.773 & 0.247 & 0.079 & 0.031 & 0.159 \\
p value & & 0.483 & 0.785 & 0.925 & 0.970 & 0.855 \\
\hline
\end{tabular}

Values are given as mean $\pm \mathrm{SD}$.

dative stress from physical activities, with consequent damage which may be different from that experienced on the ground. During physical activities, the demand for oxygen by organs in the body increases and an excessive amount of oxygen is inhaled, resulting in an increased amount of oxygen free radicals and reactive oxygen species (ROS) which can hyperoxidate polyunsaturated fatty acid in cell membranes or damage protein and DNA, and thereby damage body functions [1]. However, the body has antioxidant mechanisms comprising various antioxidant enzymes to resist such toxic effects of oxygen free radicals and ROS, so it can ease their effects or get rid of them. Antioxidant nutrients can lower the concentration of oxygen free radicals and ROS or delay their impacts [2]. A number of reports have also shown that the intake of antioxidants decreased oxidative stress resulting from exercise in humans and rodents [3-5].

Researchers generally agree that severe exercise increases the production of oxygen free radicals and ROS and consequently causes damage to DNA in the body [6], but their opinions are inconsistent as to whether regular training activates antioxidant enzymes and protects the body from oxidative stress caused by exercise [7]. Moreover, research on oxidative stress caused by exercise and changes in the activity of antioxidant enzymes has been done mostly on the ground, and few studies have been undertaken in fighter pilots and astronauts who carry out their missions in special 3-dimensional aerial environments. Alterations to the antioxidant system induced by exposure to gravitational modulation are evidenced by the modification of poly(ADP-ribose) polymerase activity, which is strongly associated with the presence of DNA damage $[8,9]$.

In his experiment on space flight with rodents and humans, Stein [10] reported that oxidative damage increased after space flight. Different from the weightless space en- vironment, air is a high-acceleration environment with excessive G-force, thus fighter pilots suffer from high physical stress, and their flights may result in the production of oxygen free radicals and ROS and consequent oxidative damage. Accordingly, not only for the individuals' health but also for national combat power, it is important to protect fighter pilots' bodies from oxidative stress during their operation in the aerial environment. However, there have been few studies in this special environment due to the difficulties in carrying out such research. It is therefore important to perform studies on these issues in the 3-dimensional aerial environment. Thus, the purpose of the present study was to use the comet assay to examine the effects of 9 weeks of regular training. It was conducted through three forms of exercise and assessed lipid peroxidation and DNA damage caused by oxidative stress that can take place in 3-dimensional space exercises that are most similar to activities in the aerial environment. In addition, this study attempted to determine whether aerial workers' regular exercise has any effect on protecting the body from oxidative stress and on maintaining homeostasis. It also aimed at analyzing differences between 3-dimensional space exercise and traditional aerobic-anaerobic exercise in overcoming oxidative stress caused by 3 -dimensional space activities.

\section{Subjects and Methods}

Study Subjects

A total of 15 healthy Korea Air Force Academy cadets were selected for our study. They were randomly divided into three groups consisting of 5 subjects each - the weight training (WT) group, the running training (RT) group and the orbotron training (OT) group. To be included in our study, they had to be nonsmokers and nondrinkers, and not to have been taking any vitamins. Informed consent was obtained from all study participants 
before performing our experiment. The physical characteristics of the study subjects are displayed in table 1 .

\section{Physical Training}

All experiments were performed from March 23rd, 2005 to June 10th of the same year. In the pretests, intensive exercise training for all participants was performed by voluntary constriction in the 3-dimensional space of an orbotron, and peripheral blood samples of each participant were collected in EDTA tubes 4 times before and after the experiments. Biochemical assay was performed on these blood samples to measure plasma lactate and malondialdehyde (MDA) concentrations, erythrocyte superoxide dismutase (SOD) activity, and lymphocyte DNA damage using the comet assay. After the pretests, members of each training group participated in a 9 -week training program. The WT was performed by the circuit WT method at the level of $80 \%$ of one repetition maximum and repeated for $8-10$ times per set for 3 sets per day. The RT consisted of running for $30 \mathrm{~min}$ per day at the level of $80 \%$ of maximum heart rate. The OT was controlled by the pace of 30 rotations per minute and the period of complete exercise was $15 \mathrm{~min}$ (5 sets of $3 \mathrm{~min}$ with 2-3 min rest between each set; 1 axis rotation for the first set with 2 min rest, 2 axis rotations for the second set with 2 min rest and 3 axis rotations for the third to fifth set with 3 min rest). After 9 weeks of training, posttests were performed in the same manner as for the pretests.

\section{Biochemical Assay}

Eight milliliters of blood were drawn from the peripheral veins of the subjects, placed in EDTA-containing tubes and immediately centrifuged for $10 \mathrm{~min}$ at $400 \mathrm{~g}$ in order to isolate the plasma. Plasma lactate concentration was measured enzymatically using an autoanalyzer (Kodak, EKTACHEM DT 60II), and the plasma MDA concentration was assayed spectrophotometrically by BIOXYTECH LPO-586 kit (Oxis, Co. Ltd., USA). Aliquots of whole blood were separated in heparin-containing tubes for erythrocyte SOD activity. The activity of erythrocyte SOD was determined in the supernatant of erythrocyte hemolysates. In brief, $1.0 \mathrm{ml}$ of heparin-treated whole blood was mixed with $0.85 \%$ $\mathrm{NaCl}$ solution, centrifuged at $1,000 \mathrm{~g}$ for $10 \mathrm{~min}$, the supernatant drained, and this step was repeated 4 times. Thereafter, the volume of this mixture was adjusted to $2.0 \mathrm{ml}$, incubated at $4^{\circ} \mathrm{C}$ for $15 \mathrm{~min}$, and finally, analyzed by using an autoanalyzer (Cobas Mira, Roche, Switzerland).

\section{Comet Assay}

Measurement of DNA damage was performed using the comet assay according to the method of Anderson et al. [11] with slight modification. In brief, $260 \mu \mathrm{l}$ of whole blood were mixed with 35 $\mu \mathrm{l}$ of $0.7 \%$ low-melting-point agarose on a glass slide, covered with a coverslip, and kept on ice for $5 \mathrm{~min}$. Thereafter, the mixture was submerged in a lysing solution ( $0.1 \mathrm{M}$ EDTA, $1 \%$ Triton X-100, $10 \%$ DMSO, $1.2 \mathrm{~g} / 1$ Tris and $146.1 \mathrm{~g} / \mathrm{l} \mathrm{NaCl}$ ), and the reaction was performed at $4^{\circ} \mathrm{C}$ for several days. Next, the slide was placed in an alkaline bath in order to denature DNA, and electrophoresis was performed for $40 \mathrm{~min}$ with a current of $300 \mathrm{~mA}$ and at $25 \mathrm{~V}$. After electrophoresis, slides were treated 3 times with $0.4 \mathrm{M}$ Tris buffer, and DNA staining was performed by the addition of $60 \mu \mathrm{l}$ ethidium bromide $(20 \mu \mathrm{g} / \mathrm{ml})$. The comet measurement was shown by a computerized comet image, and it was recorded as tail length, percentage of DNA in tail and tail moment.

Oxidative DNA Damage during

Three-Dimensional Space Exercise

\section{Statistical Analysis}

All data were expressed as means \pm SD. The paired t test was performed to analyze the difference between pre- and posttest values. One-way ANOVA was performed to compare biochemical parameters at rest, just after exercise, after $30 \mathrm{~min}$ of recovery, and after $24 \mathrm{~h}$ of recovery. Three-way ANOVA for repeated measurements was used to analyze the significant interaction effect among each training group (RT, WT or OT), each blood sample (rest, just after training, after $30 \mathrm{~min}$ of recovery or after $24 \mathrm{~h}$ of recovery) and each 3-dimensional test (pre- or posttest). Statistical significance was accepted at an $\alpha$ value of $p=0.05$. All statistical analyses were performed using the SPSS for Windows version 12.0 package.

\section{Results}

\section{Changes in Plasma Lactate, MDA Concentrations and} Erythrocyte SOD Activity

The changes in plasma lactate, MDA concentrations and erythrocyte SOD activities before and after training are displayed in table 2 and figure 1. The plasma lactate concentration was decreased after training and after 30 min of recovery in all three groups compared to before training. A three-way ANOVA to analyze the interaction effect among each training group, blood samples and each 3-dimensional test for the determination of plasma lactate concentration revealed a significant effect for blood samples $[\mathrm{F}(3,36)=196.569, \mathrm{p}<0.001]$ and each 3-dimensional test $[\mathrm{F}(1,12)=10.001, \mathrm{p}<0.05]$. The plasma MDA concentration decreased after training in all samples compared to before training. The RT group showed a statistically lower plasma MDA level at the end of exercise $(\mathrm{p}<0.05)$ and after $30 \mathrm{~min}$ of recovery $(\mathrm{p}<0.05)$ compared to before training. However, there were no statistically significant differences in blood samples taken at different times in the WT and OT groups. Among the three groups, RT showed the largest decrease in plasma MDA concentration while WT showed the smallest decrease. However, there were no statistically significant differences among all three groups under all of the experimental conditions. When a three-way ANOVA was performed, a significant effect was detected for each 3 -dimensional test $[\mathrm{F}(1,12)=$ $20.009, \mathrm{p}<0.009]$ and for blood samples $[\mathrm{F}(3,36)=18.351$, $\mathrm{p}<0.001]$. The erythrocyte SOD activity increased in all blood samples taken after training compared to before training for all three groups. SOD activity increased at rest after training rather than before training for all groups. The RT group had a statistically higher level of SOD activity after $30 \mathrm{~min}$ of recovery $(\mathrm{p}<0.05)$ compared to before training, and the OT group showed a higher level of SOD activity at rest $(\mathrm{p}<0.001)$ and after $24 \mathrm{~h}$ of recovery $(\mathrm{p}<$ $0.05)$. No statistically significant differences were found in 
Table 2. Changes in plasma lactate, MDA and erythrocyte SOD level following 3-dimensional space exercise before and after 9 weeks of training

\begin{tabular}{|c|c|c|c|c|c|c|c|}
\hline Variable & Ex. & Treat & Before & After & Recovery (30 min) & Recovery (24 h) & F value \\
\hline \multirow[t]{8}{*}{ Lactate, mmol/l } & \multirow[t]{3}{*}{ WT } & before & $1.24 \pm 0.28^{\mathrm{a}}$ & $8.04 \pm 0.40^{\mathrm{b}}$ & $4.06 \pm 0.22^{c}$ & $1.30 \pm 0.42^{\mathrm{a}}$ & $287.822^{* *}$ \\
\hline & & after & $1.44 \pm 0.58^{\mathrm{a}}$ & $6.68 \pm 0.66^{b}$ & $3.28 \pm 0.48^{c}$ & $1.44 \pm 0.40^{\mathrm{a}}$ & $61.263^{* *}$ \\
\hline & & $\mathrm{t}$ value & -1.136 & $3.245^{*}$ & $3.509^{*}$ & -0.455 & \\
\hline & \multirow[t]{2}{*}{ RT } & before & $1.06 \pm 0.11^{\mathrm{a}}$ & $7.50 \pm 1.41^{\mathrm{b}}$ & $4.24 \pm 1.09^{c}$ & $1.14 \pm 1.23^{\mathrm{a}}$ & $25.034^{* *}$ \\
\hline & & after & $1.54 \pm 0.49^{\mathrm{a}}$ & $5.58 \pm 1.12^{\mathrm{b}}$ & $3.04 \pm 0.33^{c}$ & $1.50 \pm 0.54^{\mathrm{a}}$ & $19.182^{* *}$ \\
\hline & \multirow[t]{3}{*}{ OT } & before & $1.08 \pm 0.30^{\mathrm{a}}$ & $7.94 \pm 0.99^{b}$ & $4.26 \pm 0.29^{c}$ & $1.34 \pm 0.58^{\mathrm{a}}$ & $89.210^{* *}$ \\
\hline & & after & $1.30 \pm 0.62^{\mathrm{a}}$ & $6.88 \pm 1.34^{\mathrm{b}}$ & $3.34 \pm 0.56^{\mathrm{c}}$ & $1.68 \pm 0.51^{\mathrm{a}}$ & $28.548^{* *}$ \\
\hline & & $\mathrm{t}$ value & -1.592 & 1.960 & 2.558 & -1.753 & \\
\hline \multirow[t]{5}{*}{$\mathrm{MDA}, \mathrm{nmol} / \mathrm{ml}$} & \multirow[t]{2}{*}{ WT } & before & $2.01 \pm 0.27$ & $3.06 \pm 0.94^{\mathrm{a}}$ & $2.29 \pm 0.58$ & $1.73 \pm 0.64^{b}$ & $3.830^{*}$ \\
\hline & & after & $1.64 \pm 0.28^{\mathrm{a}}$ & $2.60 \pm 0.37^{b}$ & $1.95 \pm 0.36^{\mathrm{a}}$ & $1.53 \pm 0.37^{\mathrm{a}}$ & $9.654^{*}$ \\
\hline & \multirow[t]{3}{*}{ OT } & before & $2.07 \pm 0.35$ & $3.24 \pm 0.68^{\mathrm{a}}$ & $2.55 \pm 0.91$ & $1.81 \pm 0.66^{\mathrm{b}}$ & $4.271^{*}$ \\
\hline & & after & $1.66 \pm 0.73$ & $2.59 \pm 1.13$ & $1.87 \pm 0.44$ & $1.57 \pm 0.37$ & 1.995 \\
\hline & & $\mathrm{t}$ value & 1.401 & 2.077 & 1.153 & 1.073 & \\
\hline \multirow[t]{6}{*}{$\mathrm{SOD}, \mathrm{U} / \mathrm{g} \mathrm{Hb}$} & \multirow[t]{3}{*}{ WT } & before & $612.4 \pm 269.2^{\mathrm{a}}$ & $1,301.1 \pm 597.7^{b, c}$ & $773.8 \pm 244.6^{a, c}$ & $392.4 \pm 204.5^{\mathrm{a}}$ & $5.639^{*}$ \\
\hline & & after & $676.7 \pm 297.3^{\mathrm{a}}$ & $1,400.4 \pm 575.6^{\mathrm{b}, \mathrm{c}}$ & $765.9 \pm 205.4^{\mathrm{a}, \mathrm{c}}$ & $490.4 \pm 297.9^{a}$ & $5.669^{*}$ \\
\hline & & $\mathrm{t}$ value & -1.744 & -1.529 & 0.155 & -1.870 & \\
\hline & \multirow[t]{3}{*}{ RT } & before & $646.8 \pm 234.1^{\mathrm{a}}$ & $1,373.9 \pm 410.6^{\mathrm{b}}$ & $842.6 \pm 177.4^{\mathrm{a}}$ & $558.6 \pm 200.3^{\mathrm{a}}$ & $9.053^{*}$ \\
\hline & & after & $901.5 \pm 305.6^{a}$ & $1,608.2 \pm 346.4^{b}$ & $979.7 \pm 145.5^{\mathrm{a}}$ & $654.4 \pm 139.0^{a}$ & $12.981^{*}$ \\
\hline & & t value & -2.650 & -2.375 & $-3.929^{*}$ & -1.994 & \\
\hline
\end{tabular}

Values are given as mean $\pm \mathrm{SD} .{ }^{*} \mathrm{p}<0.05 ;{ }^{* *} \mathrm{p}<0.001 .{ }^{\mathrm{a}, \mathrm{b}, \mathrm{c}}$ Significant difference between letters $(\mathrm{p}<0.05)$.

any of the blood samples from the WT group. There were no statistically significant differences among the three groups under any of the experimental conditions. The interaction analysis by three-way ANOVA indicated a significant main effect for each test $[\mathrm{F}(1,12)=30.496$, $\mathrm{p}<$ $0.001]$ and for blood samples $[\mathrm{F}(3,36)=57.825, \mathrm{p}<0.001]$, respectively.

\section{Changes in Lymphocyte Tail DNA, Tail Length and \\ Tail Moment}

The changes in lymphocyte tail DNA, tail length and tail moment before and after training are shown in table 3 and figure 2. The analysis of the comet assay to ex- amine lymphocyte DNA damage indicated that the tail DNA was significantly higher at the end of exercise compared to the other three blood samples under all of the conditions, and decreased at all blood gathering times after training compared to before training in all three groups. The three-way ANOVA indicated significant effects for each test $[F(1,12)=48.451, p<0.001]$ and for blood samples $[\mathrm{F}(3,36)=321.079, \mathrm{p}<0.001]$. The value of tail length was significantly higher at the end of exercise compared to the other three blood samples under all of the conditions, and decreased in all blood samples taken after training compared to before training in all three groups. The three-way ANOVA showed significant ef- 

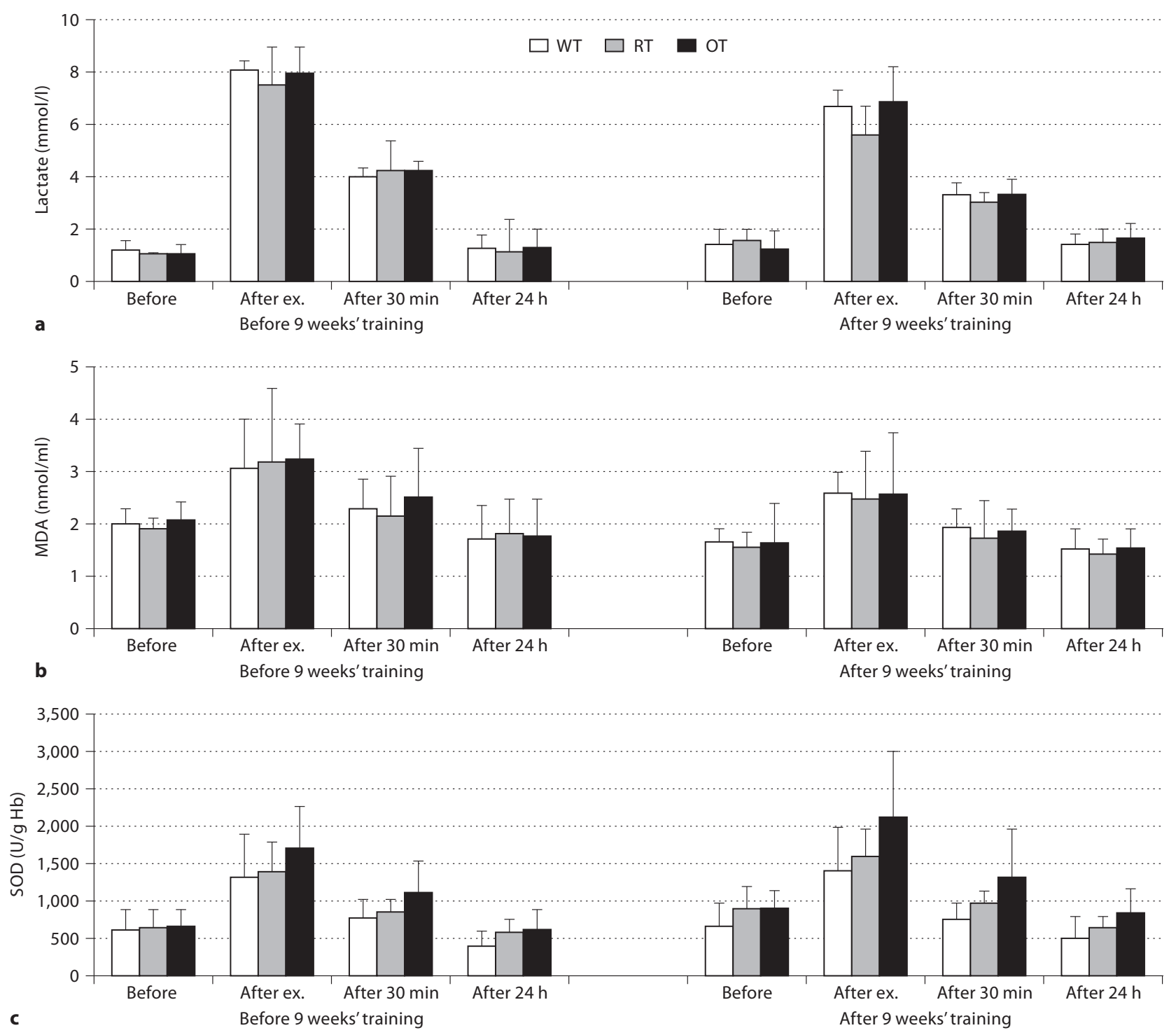

Fig. 1. Bar graph showing changes in plasma lactate (a), MDA (b) and erythrocyte SOD levels (c) before and after 9 weeks of OT.

fects for each test $[\mathrm{F}(1,12)=113.264, \mathrm{p}<0.001]$ and for blood samples $[\mathrm{F}(3,36)=45.104, \mathrm{p}<0.001]$. In the case of tail moment, analyzed by tail DNA and tail length, this value was significantly higher at the end of exercise compared to the other three blood samples under all of the conditions, and decreased in all blood samples taken after training compared to before training in all three groups. This value significantly decreased when mea- sured at rest, after $30 \mathrm{~min}$ of recovery, and after $24 \mathrm{~h}$ of recovery in the WT group $(\mathrm{p}<0.05)$ and also decreased in all blood samples in the RT and OT groups $(\mathrm{p}<0.001)$ (fig. 2). Like other parameters measured using the comet assay, the three-way ANOVA indicated significant effects for each test $[\mathrm{F}(1,12)=95.405, \mathrm{p}<0.001]$ and for blood samples $[\mathrm{F}(3,36)=553.336, \mathrm{p}<0.001]$, respectively. 

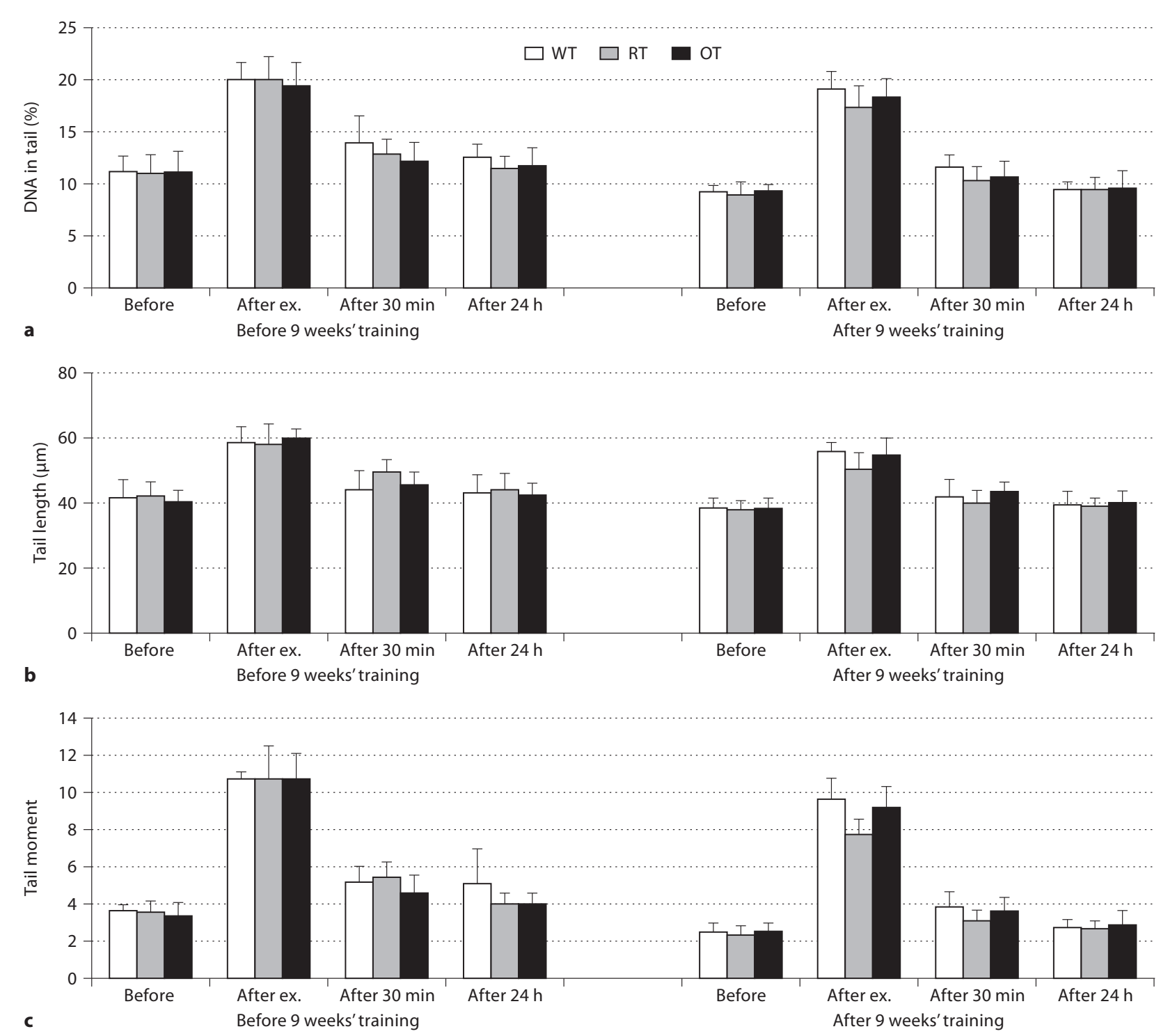

Fig. 2. Bar graph showing changes in lymphocyte tail DNA (a), tail length (b) and tail moment (c) before and after 9 weeks of OT.

\section{Discussion}

This study was conducted with air force cadets and aimed to analyze the effects of three different forms of exercise (WT, RT, OT) on lipid peroxidation, erythrocyte SOD activity, and lymphocyte DNA damage. When the effects of 9 weeks of training on the concentration of plasma lactate through each form of exercise was evaluated, the WT group showed lower concentrations of plasma lactate just after exercise and after $30 \mathrm{~min}$ of recovery after 9 weeks of training compared to values measured before training. On the other hand, the RT group showed a lower concentration of plasma lactate at rest before the 9 weeks of training and just after exercise after the 9 weeks of training. The OT group did not show any statistically significant difference among any of the blood samples taken at different times. In addition, all three groups showed the highest plasma lactate concentration just af- 
Table 3. Changes in lymphocyte tail DNA (TD), tail length (TL) and tail moment (TM) following 3-dimensional space exercise before and after 9 weeks of training

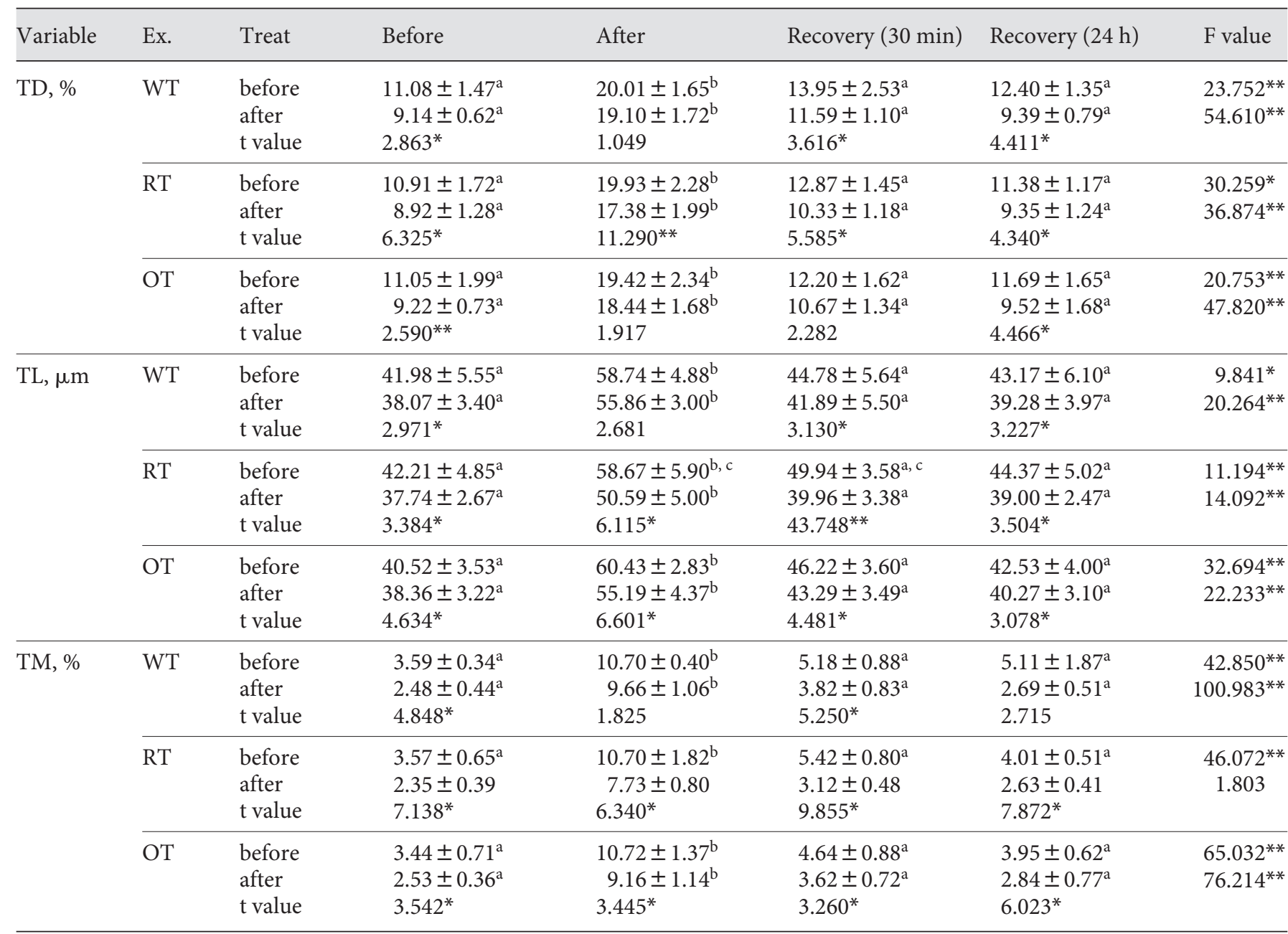

Values are given as mean $\pm \mathrm{SD} .{ }^{*} \mathrm{p}<0.05 ;{ }^{* *} \mathrm{p}<0.001 .{ }^{\mathrm{a}, \mathrm{b}, \mathrm{c}}$ Significant difference between letters $(\mathrm{p}<0.05)$.

ter exercise compared to the other three blood samples (at rest, after $30 \mathrm{~min}$ of recovery, and after $24 \mathrm{~h}$ of recovery). In addition, despite the increase in the concentration of plasma lactate when measured at rest after the 9 weeks of training, all three groups showed a lower plasma lactate concentration just after exercise and after $30 \mathrm{~min}$ of recovery after the 9 weeks of training compared to the value measured before training. Specifically, just after exercise, the concentration decreased by $16.5 \%$ in the WT group, $25.7 \%$ in the RT group and $21.6 \%$ in the OT group. These results suggest that if physical strength increases through training, the intensity of exercise felt by the body becomes lower for the same load of exercise, and as a result less lactate is produced. From this viewpoint, the three types of exercise applied in this study were all effective. In addition, the reason for the larger decrease in the RT group compared to the other groups may be due to metabolic adjustments caused by aerobic training such as the increase of enzymes involved in aerobic metabolism and the increase of blood flow that took place as a way of decreasing the accumulation of lactate. The results of analyzing the effects of 9 weeks of training on the concentration of plasma MDA caused by oxidative stress in each form of exercise showed that all three groups demonstrated a tendency for the concentration to decrease in all blood samples taken after training compared to the values measured before training. After the 9 weeks of training, the WT group showed an $18.4 \%$ decrease when mea- 
sured at rest, $15.0 \%$ just after exercise, $14.5 \%$ after $30 \mathrm{~min}$ of recovery and $11.6 \%$ after $24 \mathrm{~h}$ of recovery; the RT group had 18.6, 22.2, 19.4 and $21.7 \%$ decreases, respectively, and the OT group 19.8, 20.0, 26.7 and 13.3\% decreases, respectively. Moreover, in comparison within the groups, just after exercise after the 9 weeks of training, the WT and RT groups showed increases in the concentration of plasma MDA ( $\mathrm{p}<0.05)$, but values in the OT group remained unchanged compared to the measurement at rest $(p>0.05)$. Therefore, our data support previous reports that training of the same intensity decreased the concentration of plasma MDA $[12,13]$. In addition, our data suggest that training under the same environmental conditions decreased the concentration of plasma MDA in special 3-dimensional environmental exercise.

In general, intense exercise can increase oxidative stress and consequently result in various tissue damages including lipid, protein and DNA. The major cause of oxidative damage is attack by ROS, and ROS has little clinical significance. In their special 3-dimensional environment, air force pilots would experience much more oxidative stress than those on the ground. However, because it is dismutated by the antioxidant defense system, SOD is present in tissue to convert $\mathrm{O}_{2}^{-}$to $\mathrm{H}_{2} \mathrm{O}_{2}$ and $\mathrm{H}_{2} \mathrm{O}_{2}$ to $\mathrm{H}_{2} \mathrm{O}$ and $\mathrm{O}_{2}$ [14]. Deficient or inactive SOD enzyme elevates $\mathrm{O}_{2}{ }^{-}$levels in intact blood vessels. In this study, SOD activity significantly increased after training in the OT group. Some reports on the efficacy of endurance training to antioxidant enzyme activity consistently suggest that regular endurance exercise training and OT stimulate cytosolic and mitochondrial antioxidant enzyme activity $[7,15-18]$ with a greater increase in the mitochondria fraction $[19,20]$.

Lymphocyte DNA tail length and DNA tail moment are biomarkers for DNA oxidative damage in humans. DNA damage increases remarkably in human serum after exercise, as reported previously [21]. When the comet assay was performed in this study in order to see the effects of the 9 weeks of training on lymphocyte DNA damage according to the form of exercise under all experimental conditions, the damage level was statistically higher just after exercise than in all three blood samples taken at different times, and these three parameters were similar in all three groups studied. This shows that the three types of training applied in this study decrease lymphocy te DNA damage. Statistically, the WT group showed significant decreases in all three parameters at rest, after $30 \mathrm{~min}$ of recovery and after $24 \mathrm{~h}$ of recovery during the 9 weeks of training, and the RT group showed significant decreases for all three parameters in all blood samples taken after the 9 weeks of training. In addition, the OT group showed a significant decrease in tail DNA when measured after $24 \mathrm{~h}$ of recovery and significant decreases in tail length and tail moment in all blood samples taken after the 9 weeks of training. According to the literature, a bout of exercise is considered to cause oxidative stress and to increase DNA damage [22], but it is still controversial as to what effects long-term training has on DNA damage in the human body. Although it is considered more likely that regular training decreases DNA damage [23-25], there are also reports that it failed to decrease DNA damage [26, 27].

DNA damage depends on antioxidant defense capacity because the postexercise DNA damage level in people with higher antioxidant protection capacity was $60 \%$ lower than in subjects with lower antioxidant protection capacity [28]. As a result, low lymphocyte DNA damages in the RT and OT groups are caused at least in part by the high SOD activity levels due to aerobic training and/or OT. As discussed above, the explanation for these results is that regular aerobic and/or orbotron exercise increased the activity of erythrocyte SOD against oxidative stress and therefore strengthened the body's resistance and homeostasis to overcome harmful effects resulting from the production of ROS. Accordingly, regular aerobic and/or orbotron exercise is considered to produce beneficial effects for the body to adjust itself to repeated oxidative stress.

\section{Conclusion}

The three types of exercise executed during 9 weeks of training in this study resulted in a decrease in the concentration of plasma lactate through 3-dimensional space exercise. In addition, it was found that 9 weeks of training with three types of exercise increased the activity of antioxidant enzyme and consequently decreased the concentration of plasma MDA and lymphocyte DNA damage. With regard to the effect of 3-dimensional space exercise on overcoming oxidative stress, no statistically significant difference was observed in the effect of 9 weeks of training between traditional aerobic-anaerobic exercise and 3-dimensional space exercise. 


\section{References}

1 Mastaloudis A, Yu TW, O’Donnell RP, Frei B, Dashwood RH, Traber MG: Endurance exercise results in DNA damage as detected by the comet assay. Free Radic Biol Med 2004;36:966-975.

$>2$ Sen CK: Oxidants and antioxidants in exercise. J Appl Physiol 1995;79:675-686.

$>3$ Sen CK, Atalay M, Hanninen O: Exercise induced oxidative stress: glutathione supplementation and deficiency. J Appl Physiol 1994;77:2177-2187.

$\checkmark 4$ Ibrahim W, Tatumi V, Yeh CC, Hong CB, Chow CK: Effects of dietary carnosine and vitamin $\mathrm{E}$ on antioxidant and oxidative status of rats. Int J Vitam Nutr Res 2008;78:230 237.

$\checkmark 5$ Sen CK, Atalay M, Agren J, Laaksonen DE, Roy S, Hanninen O: Fish oil and vitamin E supplementation in oxidative stress at rest and after physical exercise. J Appl Physiol 1997;83:189-195.

$\checkmark 6$ Moller P, Loft S, Lundby C, Olsen NV: Acute hypoxia and hypoxic exercise induce DNA strand breaks and oxidative DNA damage in humans. FASEB J 2001;15:1181-1186.

$>7$ Ji LL: Antioxidant enzyme response to exercise and aging. Med Sci Sports Exerc 1993;25: 225-231.

$>8$ Degan P, Cesarone CF, Ottaggio L, Galleri G, Meloni MA, Zunino A, Viaggi S, Bonatti S, Abbondandolo A: Effects of simulated microgravity on metabolic activities related to DNA damage and repair in lymphoblastoid cells. J Gravit Physiol 2001;8:P21-P22.

$>9$ Degan P, Sancandi M, Zunino A, Ottaggio L, Viaggi S, Cesarone F, Pippia P, Galleri G, Abbondandolo A: Exposure of human lymphocytes and lymphoblastoid cells to simulated microgravity strongly affects energy metabolism and DNA repair. J Cell Biochem 2005; 94:460-469.

10 Stein TP: Space flight and oxidative stress. Nutrition 2002;18:867-871.
11 Anderson D, Yu TW, Wright J, Ioannides C: An examination of DNA strand breakage in the comet assay and antioxidant capacity in diabetic patients. Mutat Res 1998;398:151161.

12 Salminen A, Vihko V: Endurance training reduces the susceptibility of mouse muscle to lipid peroxidation in vitro. Acta Physiol Scand 1983;117:105-110.

13 Sumida S, Tanaka K, Kitao H, Nakadomo F: Exercise-induced lipid peroxidation and leakage of enzymes before and after vitamin E supplementation. Int J Biochem 1989;21: 835-838.

14 Demling R, LaLonde C, Saldinger P, Knox J: Multiple-organ dysfunction in the surgical patient: pathophysiology, prevention, and treatment. Curr Probl Surg 1993;30:345414.

15 Bloomer RJ, Goldfarb AH: Anaerobic exercise and oxidative stress. Can J Appl Physiol 2004;29:245-263.

16 Hellsten Y, Apple FS, Sjodin B: Effect of sprint cycle training on activities of antioxidant enzymes in human skeletal muscle. J Appl Physiol 1996;81:1484-1487.

17 Higuchi M, Cartier L, Chen JM, Holloszy JO: Superoxide dismutase and catalase in skeletal muscle: adaptive response to exercise. J Gerontol 1985;40:281-286.

18 Quintanilha AT: The effect of physical exercise and/or vitamin $\mathrm{E}$ on tissue oxidative damage. Ciba Found Symp 1984;101:56-69.

19 Reddy CP, Fernandes G: Modulation of antioxidant enzymes and lipid peroxidation in salivary gland and other tissues in mice by moderate treadmill exercise. Aging 1999;11: 246-252.

20 Vincent HK, Powers SK, Stewart DJ, Demirel HA, Shanely RA, Naito H: Short-term exercise training improves diaphragm antioxidant capacity and endurance. Eur J Appl Physiol 2000;81:67-74.
21 Tsakiris S, Parthimos T, Parthimos N, Tsakiris T, Schulpis K: The beneficial effect of L-cysteine supplementation on DNA oxidation induced by forced training. Pharmacol Res 2006;53:386-390.

22 Wierzba TH, Olek RA, Fedeli D, Falcioni G: Lymphocyte DNA damage in rats challenged with a single bout of strenuous exercise. J Physiol Pharmacol 2006;57(suppl 10):115131.

23 Okamura K, Doi T, Hamada K, Sakurai M, Yoshioka Y, Mitsuzono R, Migita T, Sumida S, Sugawa-Katayama Y: Effect of endurance exercise on the tissue 8-hydroxydeoxyguanosine content in dogs. Free Radic Res 1997;26:523-528.

24 Radak Z, Kaneko T, Tahara S, Nakamoto H, Ohno H, Sasvari M, Nyakas C, Goto S: The effect of exercise training on oxidative damage of lipids, proteins and DNA in rat skeletal muscle: evidence for beneficial outcomes. Free Radic Biol Med 1999;27:69-74.

25 Radak Z, Pucsok J, Mecseki S, Csont T, Ferdinandy P: Muscle soreness-induced reduction in force generation is accompanied by increased nitric oxide content and DNA damage in human skeletal muscle. Free Radic Biol Med 1999;26:1059-1063.

26 Demirbağ R, Yilmaz R, Güzel S, G̦elik H, Koçyigit A, Özcan E: Effects of treadmill exercise test on oxidative/antioxidative parameters and DNA damage. Anadolu Kardiyol Derg 2006;6:135-140.

27 Pilger A, Germadnik D, Formanek D, Zwick H, Winkler N, Rudiger HW: Habitual longdistance running does not enhance urinary excretion of 8-hydroxydeoxyguanosine. Eur J Appl Physiol 1997;75:467-469.

28 Kinnaert E, Duez P, Morandini R, Dubois J, van Houtte P, Ghanem G: Cysteine but not glutathione modulates the radiosensitivity of human melanoma cells by affecting both survival and DNA species. Pigment Cell Res 2004; 17:275-280. 